\title{
Electrophysiologic Effects of Pindolol on Atrioventricular Conduction in Canine Heart
}

\author{
Takemi Arakawa, M.D., Tadashi Kambe, M.D., \\ and Nobuo Sakamoto, M.D.
}

\section{SUMmary}

The effects of intravenous pindolol on the electrophysiologic properties of the atrioventricular conduction system was studied in intact dog, using His bundle electrogram and the extrastimulus method.

Pindolol was administered intravenously in a dose range of 4 to $40 \mu \mathrm{g} / \mathrm{Kg}$. The latter dosage of pindolol is above those used clinically.

Significant effects of intravenous pindolol were observed on sinus cycle length, the A-V nodal conduction time, the ERP of the atrium, the ERP and FRP of the A-V node, and the ERP of the ventricle.

Sinus cycle length was prolonged during sinus rhythm. Intraatrial conduction time was not altered by pindolol, while the ERP of the atrium was slightly increased. The A-H interval was generally prolonged by pindolol without Wenckebach type A-V block, but the $\mathrm{H}-\mathrm{V}$ interval was unchanged. Both ERP and FRP of the A-V node were prolonged.

The ERP and RRP of the His-Purkinje system were not statistically evaluated, because no block within the His-Purkinje system or prolongation of $\mathrm{H}-\mathrm{V}$ interval was produced and only a few QRS complexes by extrastimulus showed aberrant configration in the intact canine heart.

In addition, pindolol prolonged the ERP of the ventricle.

\section{Additional Indexing Words:}

Atrioventricular conduction system His bundle electrogram Extrastimulus method Effective refractory period Beta-adrenergic blocking properties Membrane stabilizing action

RECENTLY, various beta-adrenergic receptor blockades have been used Many studies have described electrophysiologic and pharmacologic actions of beta-blocking agents. ${ }^{51-8)}$ The mechanism of antiarrhythmic action of betablocking drugs, however, still remains to be elucidated. Pindolol is a betaadrenergic receptor blocking agent with the following chemical structure,

From the Third Department of Internal Medicine, Nagoya University, School of Medicine, Nagoya.

Address for reprint: Takemi Arakawa, M.D., Third Department of Internal Medicine, 65 Tsurumai-cho, Showa-ku, Nagoya 466, Japan.

Received for publication December $16,1978$. 
4-(2-hydroxy-3-isopropylaminopropoxy)-indole. The purpose of the present study was to evaluate the effects of pindolol on the conduction times and the refractory periods of the atrioventricular conduction system of canine heart using His bundle electrogram and the extrastimulus method.

\section{Materials and Methods}

In the present study, dogs weighing 8 to $20 \mathrm{Kg}$ were anesthetized with intravenous sodium pentobarbital $(35 \mathrm{mg} / \mathrm{Kg})$. They were intubated, placed on artificial ventilation and supplied with $100 \%$ oxygen, without opening the chest throughout the experiment.

For the first experiment, 40 dogs were used to evaluate the effects of pindolol on sinus cycle length and the conduction times of the atrioventricular conduction system. They were divided into 4 groups of 10 dogs each. A hexapolar catheter (ELECATH) was percutaneously introduced into the right femoral vein and positioned across the tricuspid valve to record the electrical activity from the bundle of His. The proximal terminals of the electrode catheter were plugged into a multichannel distribution switch box which permitted the selection of any 2 electrodes for bipolar recordings. Care was taken to insure adequate grounding of all equipments by data display on a multichannel oscilloscope of Fukuda Electro Co, Ltd, MCM-8000. A bipolar catheter was positioned at the high right atrium via the right jugular vein. The standard electrocardiogram (Lead II or Lead I, II, III) was simultaneously recorded on photographic paper at a speed of $250 \mathrm{~mm} / \mathrm{sec}$ by Sanei-sokki Co, Ltd, Model 100A. Time lines were generated at intervals of 10 and $100 \mathrm{msec}$. Pindolol was administered into the left femoral vein for $3 \mathrm{~min}$ at doses of $4 \mu \mathrm{g} / \mathrm{Kg}, 20 \mu \mathrm{g} / \mathrm{Kg}, 40 \mu \mathrm{g} / \mathrm{Kg}$ to groups 1, 2, and 3, respectively. Group 4 was used for control.

This first experiment was undertaken for $60 \mathrm{~min}$. Sinus cycle length, the P-A, A-H, H-V, and QRS intervals were measured according to Hecht and associates. ${ }^{91}$

Secondly, studies on the refractory periods of the atrium, A-V node and HisPurkinje system were performed by the extrastimulus method. Another bipolar catheter was inserted into the high right atrium via the left jugular vein. The basic driving stimulus $\left(S_{1}\right)$ at a rate slightly faster than the underlying sinus rate and the extrastimulus $\left(\mathrm{S}_{2}\right)$ were delivered from Electronic Stimulator 3F-31 (Saneisokki Co, Ltd). The extrastimulus was introduced after every 8 beats, moving progressively earlier by $5 \mathrm{msec}$ decrements in successive test cycles. The refractory period of the ventricle was measured by the extrastimulus method under right ventricular pacing. In these studies on the refractory periods, intravenous pindolol was administered in doses of $4 \mu \mathrm{g} / \mathrm{Kg}, 20 \mu \mathrm{g} / \mathrm{Kg}$, and $40 \mu \mathrm{g} / \mathrm{Kg}$, respectively, to other 10 dogs each in the same way as in the first experiment. Then the same experiment was carried out.

In the third experiment, the effects of pindolol on the atrioventricular conduction times under atrial pacing, were evaluated by administration of $4 \mu \mathrm{g} / \mathrm{Kg}$ and $40 \mu \mathrm{g} / \mathrm{Kg}$, respectively, to 2 groups of $10 \mathrm{dogs}$ each. The result under atrial pacing was compared with that without pacing in the first experiment. 
Definition of the terms:

The P-A interval as measured from the onset of the $\mathrm{P}$ wave to the onset of the atrial electrogram, was taken as a measure of intraatrial conduction time.

The A-H interval as measured from the onset of the atrial electrogram to the first high frequency component of the His bundle electrogram, was taken as a measure of $\mathrm{A}-\mathrm{V}$ nodal conduction time.

The $\mathrm{H}-\mathrm{V}$ interval as measured from initial deflection of His potential to the earliest point of ventricular depolarization, was taken as a measure of His-Purkinje conduction time.

$A_{1}, H_{1}$, and $V_{1}$ represent the atrial, His bundle, and ventricular electrograms of the basically driven beats.

$A_{2}, H_{2}$, and $V_{2}$ represent the atrial, $H i s$ bundle, and ventricular electrograms in response to $S_{2}$.

The effective refractory period (ERP) of the atrium is defined as the longest $S_{1}-S_{2}$ interval at which $S_{2}$ fails to depolarize the atrium.

The ERP of the $A-V$ node is the longest $A_{1}-A_{2}$ interval at which $A_{2}$ depolarizes the atrium but fails to depolarize the His bundle.

The functional refractory period (FRP) of the A-V node is defined as the shortest $\mathrm{H}_{1}-\mathrm{H}_{2}$ interval that results from any $\mathrm{A}_{1}-\mathrm{A}_{2}$ interval.

The ERP of the His-Purkinje system is defined as the longest $\mathrm{H}_{1}-\mathrm{H}_{2}$ interval at which $\mathrm{H}_{2}$ fails to conduct to the ventricles.

The relative refractory period (RRP) of the His-Purkinje system is defined as the longest $\mathrm{H}_{1}-\mathrm{H}_{2}$ interval at which $\mathrm{H}_{2}$ conducts to the ventricles with a longer $\mathrm{H}-\mathrm{V}$ interval than that of the basic drive beat or with a $Q R S$ of aberrant configuration.

The ERP of the ventricle is defined as the longest $S_{1}-S_{2}$ interval at which $S_{2}$ fails to depolarize the ventricle during ventricular pacing.

\section{RESULTS}

The results are summarized in Tables I and II. Mean values given in these tables were calculated in each group composed of 10 dogs.

Sinus cycle length (SCL):

Administration of pindolol resulted in prolongation of SCL which occurred within $5 \mathrm{~min}$ after venous injection of pindolol. The mean change of the heart rate was a $12 \%$ decrease in group 1 , an $18 \%$ decrease in group 2 and a $19 \%$ decrease in group 3 , respectively $(p<0.001)$, while there was no significant change in the control group.

Conduction time:

The results of conduction time are summarized in Table I.

Intraatrial conduction time. Pindolol had no effect on the P-A interval during sinus rhythm.

A-V nodal conduction time. Table I summarizes the effects of pindolol on $\mathrm{A}-\mathrm{V}$ nodal conduction time as measured by $\mathrm{A}-\mathrm{H}$ interval during sinus rhythm. The A-H interval was increased by pindolol (mean $+5 \mathrm{msec}$ in 
Table I. Effects of Pindolol on Sinus Cycle Length and the Conduction Times

\begin{tabular}{|c|c|c|c|c|c|c|c|c|c|c|}
\hline & \multicolumn{2}{|c|}{ SCL } & \multicolumn{2}{|c|}{ A-H interval } & \multicolumn{2}{|c|}{$\mathrm{H}-\mathrm{V}$ interval } & \multicolumn{2}{|c|}{ P-A interval } & \multicolumn{2}{|c|}{ QRS interval } \\
\hline & Before & After & Before & After & Before & After & Before & After & Before & After \\
\hline $\begin{array}{l}\text { Pindolol } \\
4 \mu \mathrm{g} / \mathrm{kg} \\
(\mathrm{n}=10)\end{array}$ & $335 \pm 28$ & $382 \pm 32$ & $46 \pm 6$ & $51 \pm 6$ & $24 \pm 3$ & $24 \pm 3$ & $12 \pm 1$ & $12 \pm 1$ & $38 \pm 4$ & $38 \pm 4$ \\
\hline $\begin{array}{l}\text { Pindolol } \\
20 \mu \mathrm{g} / \mathrm{kg} \\
(\mathrm{n}=10)\end{array}$ & $348 \pm 22$ & $421 \pm 24$ & $46 \pm 5$ & $54 \pm 6$ & $23 \pm 2$ & $23 \pm 2$ & $13 \pm 1$ & $13 \pm 1$ & $39 \pm 4$ & $39 \pm 4$ \\
\hline $\begin{array}{l}\text { Pindolol } \\
40 \mu \mathrm{g} / \mathrm{kg} \\
(\mathrm{n}=10)\end{array}$ & $320 \pm 24$ & $400 \pm 30$ & $45 \pm 6$ & $55 \pm 8$ & $26 \pm 3$ & $26 \pm 3$ & $13 \pm 1$ & $13 \pm 1$ & $40 \pm 4$ & $40 \pm 4$ \\
\hline $\begin{array}{l}\text { Control } \\
(n=10)\end{array}$ & $329 \pm 30$ & $328 \pm 30$ & $45 \pm 3$ & $45 \pm 3$ & $22 \pm 2$ & $22 \pm 2$ & $12 \pm 1$ & $12 \pm 1$ & $37 \pm 4$ & $37 \pm 3$ \\
\hline
\end{tabular}

All values are mean $\pm \mathrm{SEM}$ (in $\mathrm{msec}$ ). $\mathrm{SCL}=$ sinus cycle length.

Table II. Effects of Pindolol on the Refractory Periods

\begin{tabular}{|c|c|c|c|c|c|c|c|c|}
\hline & \multicolumn{2}{|c|}{ ERP of the atrium } & \multicolumn{2}{|c|}{$\begin{array}{l}\text { ERP of the } \\
\text { A-Vnode }\end{array}$} & \multicolumn{2}{|c|}{$\begin{array}{l}\text { FRP of the } \\
\text { A-Vnode }\end{array}$} & \multicolumn{2}{|c|}{$\begin{array}{l}\text { ERP of the } \\
\text { ventricle }\end{array}$} \\
\hline & Before & After & Before & After & Before & After & Before & After \\
\hline $\begin{array}{l}\text { Pindolol } \\
4 \mu \mathrm{g} / \mathbf{k g} \\
(\mathrm{n}=10)\end{array}$ & $130 \pm 16$ & $140 \pm 16$ & $137 \pm 14$ & $149 \pm 16$ & $219 \pm 14$ & $231 \pm 14$ & $150 \pm 11$ & $157 \pm 9$ \\
\hline $\begin{array}{l}\text { Pindolol } \\
20 \mu \mathrm{g} / \mathrm{kg} \\
(\mathrm{n}=10)\end{array}$ & $126 \pm 10$ & $135 \pm 11$ & $134 \pm 11$ & $148 \pm 16$ & $215 \pm 13$ & $235 \pm 14$ & $148 \pm 9$ & $157 \pm 9$ \\
\hline $\begin{array}{l}\text { Pindolol } \\
40 \mu \mathrm{g} / \mathrm{kg} \\
(\mathrm{n}=10)\end{array}$ & $129 \pm 15$ & $140 \pm 14$ & $138 \pm 12$ & $161 \pm 15$ & $213 \pm 13$ & $245 \pm 14$ & $151 \pm 11$ & $161 \pm 9$ \\
\hline $\begin{array}{l}\text { Control } \\
(n=10)\end{array}$ & $133 \pm 11$ & $135 \pm 10$ & $139 \pm 10$ & $140 \pm 11$ & $214 \pm 12$ & $215 \pm 12$ & $147 \pm 9$ & $148 \pm 9$ \\
\hline
\end{tabular}

All values are mean $\pm S E M$ (in msec). $E R P=$ effective refractory period; $F R P=$ functional refractory period.

group 1, mean +8 msec in group 2 , mean +10 msec in group $3, \mathrm{p}<0.001$ ). The doses of pindolol did not cause second or third degree A-V block. Fig. 1 illustrates the prolongation of the A-H interval in a case of group 3 . In the control group, no significant change of the A-H interval was recognized.

His-Purkinje conduction time. The $\mathrm{H}-\mathrm{V}$ interval, which approximates the conduction time through the His-Purkinje system, remained unchanged both in pindolol and control groups.

The QRS interval. Pindolol had no effect on the QRS interval during sinus rhythm. No aberrant ventricular conduction occurred after intravenous 


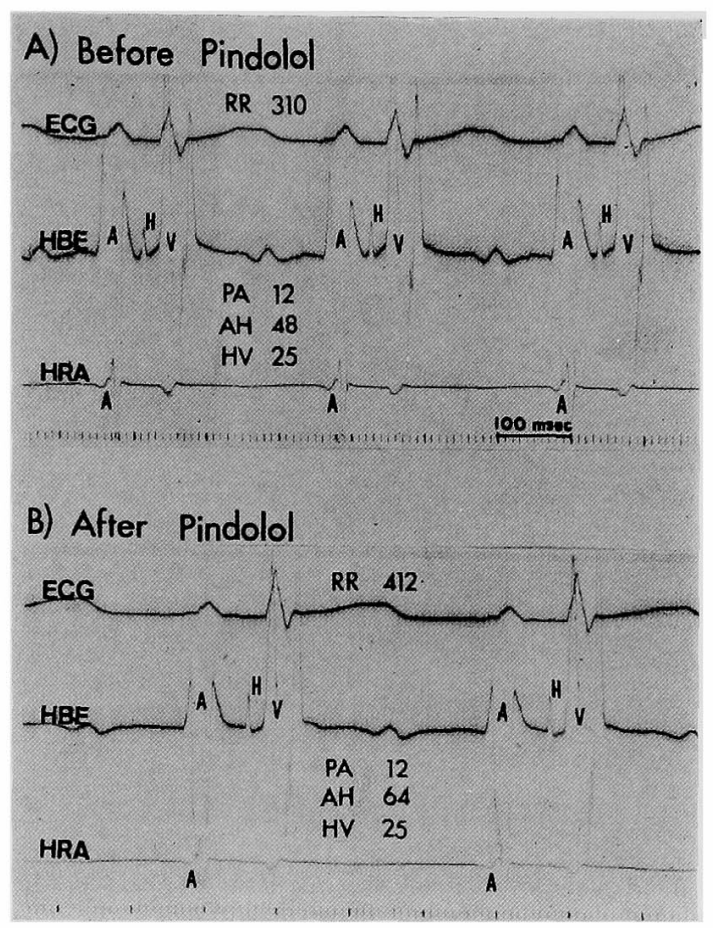

Fig. 1. Effects of pindolol on sinus cycle length and atrioventricular conduction times. Simultaneous electrocardiographic lead II (ECG), His bundle electrogram (HBE), and high right atrial electrogram (HRA) are shown with time lines of 10 and $100 \mathrm{msec}$. $A, H$, and $V$ represent atrial electrogram, His bundle electrogram, and ventricle electrogram. In the upper panel, spontaneous sinus cycle length is $310 \mathrm{msec}$, whereas $5 \mathrm{~min}$ after intravenous administration of $40 \mu \mathrm{g} / \mathrm{Kg}$ of pindolol, it increases to $412 \mathrm{msec}$. The A-H interval increases from $48 \mathrm{msec}$ to $64 \mathrm{msec}$. The P-A and H-V intervals remain constant at $12 \mathrm{msec}$ and $25 \mathrm{msec}$, respectively.

administration of pindolol.

Refractory periods:

The results of refractory periods are summarized in Table II.

ERP of the atrium. The effective refractory period of the atrium was increased by intravenous pindolol (Fig. 2).

The differences were small and not sufficiently significant among the mean ERPs of the atrium in pindolol groups. Control group showed no significant change.

ERP of the A-V node. The effective refractory period of the A-V node was prolonged in pindolol groups (Fig. 3). In group 3, the mean ERP of the A-V node was increased from $138 \mathrm{msec}$ to $161 \mathrm{msec}$.

FRP of the A-V node. The administration of pindolol resulted in prolongation of the FRP of the A-V node. The mean FRP of the A-V node was 

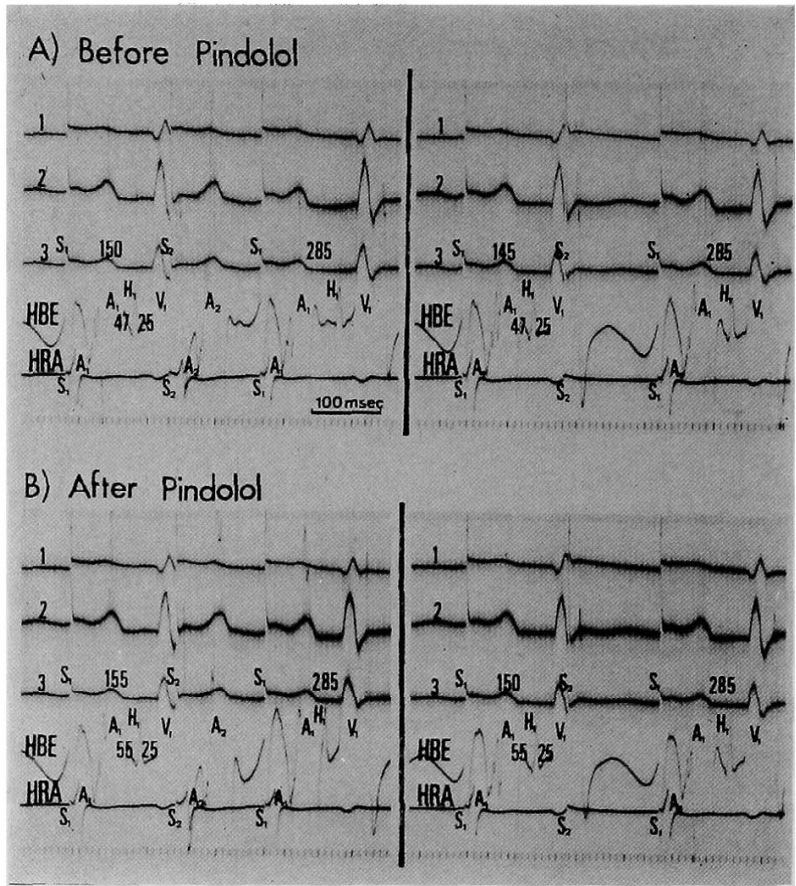

Fig. 2. Effects of pindolol on the ERP of the atrium in a case of group 3. Two panels show from top to bottom standard electrocardiographic leads 1, 2, 3, His bundle electrogram (HBE) and high right atrial electrogram (HRA). $S_{1}, A_{1}, H_{1}$, and $V_{1}$ represent the stimulus artifact, atrial electrogram, His bundle potential and ventricular electrogram of the basic drive beat. $\mathrm{S}_{2}$ and $A_{2}$ represent stimulus artifact and atrial electrogram of the premature beat. In this case, the paced cycle length shows a $S_{1}-S_{1}$ interval of 285 msec. Before administration of pindolol (upper panel), the $S_{1}-S_{2}$ interval of 145 msec fails to capture the atrium. In the lower panel, $5 \mathrm{~min}$ after intravenous administration of $40 \mu \mathrm{g} / \mathrm{Kg}$ of pindolol the $S_{1}-S_{2}$ intreval of $150 \mathrm{msec}$ fails to capture the atrium. Thus, the ERP of the atrium is increased by $5 \mathrm{msec}$ after intravenous administration of pindolol.

prolonged from 219 to $231 \mathrm{msec}$ in group 1, 215 to $235 \mathrm{msec}$ in group 2, 213 to $245 \mathrm{msec}$ in group 3 , respectively. The control group did not significantly affect the FRP of the A-V node.

ERP and RRP of the His-Purkinje system. Since no block within the His-Purkinje system or prolongation of $\mathrm{H}-\mathrm{V}$ interval was produced and only a few QRS complexes by extrastimulus showed aberrant configuration in the intact canine heart, the ERP and RRP of the His-Purkinje system were not statistically evaluated.

ERP of the ventricle. Intravenous pindolol prolonged the ERP of the ventricle. Fig. 4 is a case of group 2. Increase rates of the ERP of the ventricle in pindolol groups were about $4 \%$ in group $1,6 \%$ in group $2,6 \%$ 


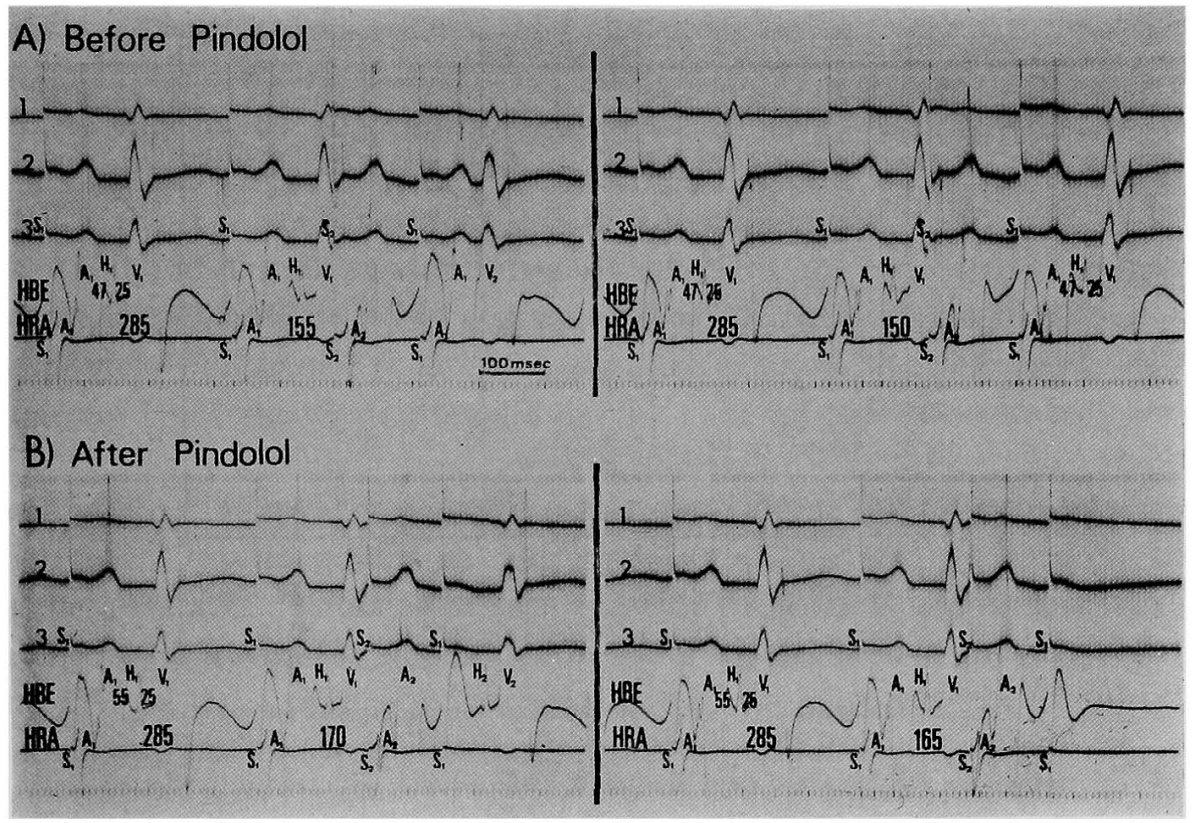

Fig. 3. Effects of pindolol on the ERP of the A-V node. This is the same case as Fig. 2. The basic paced atrial cycle length is $285 \mathrm{msec}$. Before administration of pindolol (upper panel), the ERP of the A-V node amounts to an $A_{1}-A_{2}$ interval of $150 \mathrm{msec}$. Five min after administration of pindolol (lower panel), block of $A$ above the His bundle occurs at an $A_{1}-A_{2}$ interval of $165 \mathrm{msec}$. Thus, the ERP of the A-V node is increased by $15 \mathrm{msec}$.

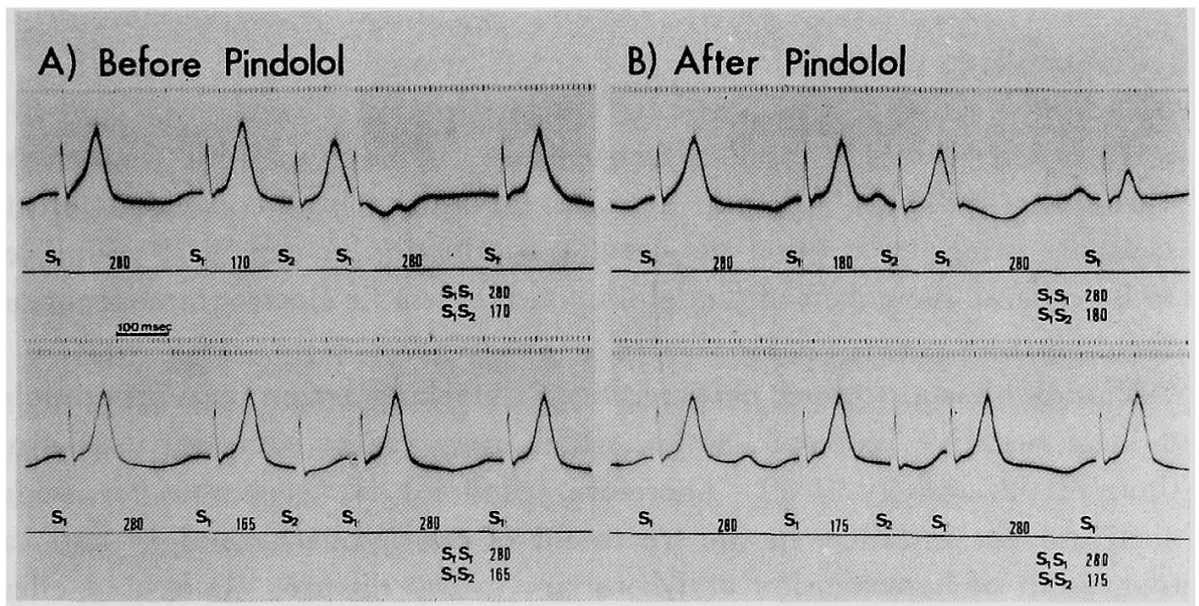

Fig. 4. Effects of pindolol on the ERP of the ventricle in a case of group 2. The basic paced ventricular cycle length is $280 \mathrm{msec}$. Before administration of pindolol (upper panel), the ERP of the ventricle is reached at the longest $S_{1}-S_{2}$ interval of $165 \mathrm{msec}$ at which $S_{2}$ fails to depolarize the ventricle during ventricular pacing. After administration of pindolol (lower panel), $S_{2}$ fails to depolarize the ventricle at a $S_{1}-S_{2}$ interval of $175 \mathrm{msec}$. The ERP of the ventricle, therefore, is increased by $10 \mathrm{msec}$. 


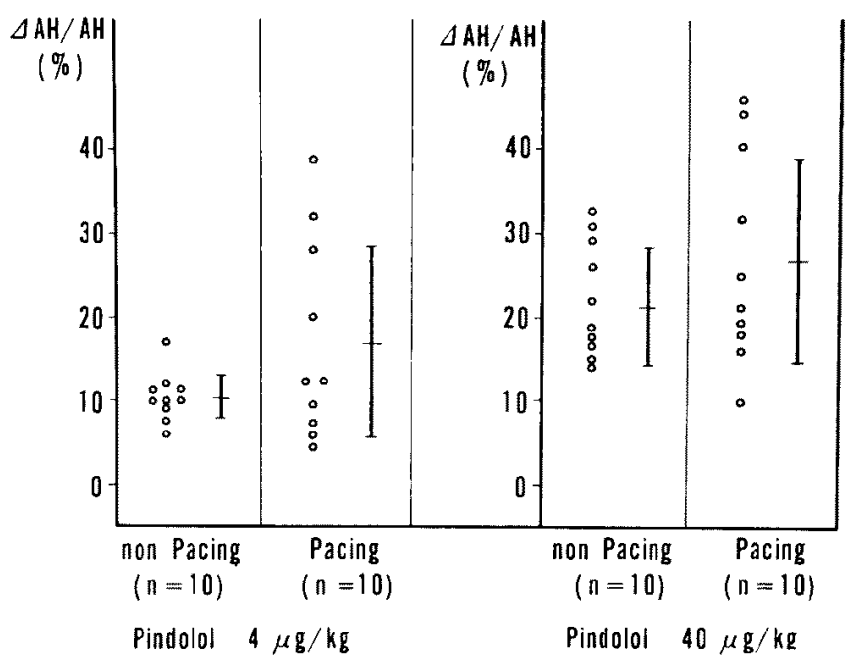

Fig. 5. Comparison of $\triangle \mathrm{AH} / \mathrm{AH}$ between non pacing and pacing studies. This figure shows that the result without pacing in the first experiment is statistically less dispersed than that under atrial pacing, with regard to effects of pindolol on the atrioventricular conduction time.

in group 3, respectively.

Finally, Fig. 5 shows that the result without pacing in the first experiment was statistically less dispersed than that under atrial pacing, with regard to the effects of pindolol on the atrioventricular conduction time.

\section{Discussion}

In recent years, $H$ is bundle electrogram has proven useful in the analysis of various arrhythmias ${ }^{10-14}$ ) and it is also thought to be a convenient means to evaluate drug action upon the cardiac conduction system. ${ }^{15)-21)}$ This led us to investigate the effects of pindolol upon His bundle electrogram in normal canine hearts.

Pindolol has a stronger beta-adrenergic blocking action than propranolol and little negative inotropic action which may reflect some intrinsic sympathomimetic activity. ${ }^{22-24)}$ Therefore, pindolol is acceptable for wider clinical use, for instance, in the treatment of cardiac arrhythmia ${ }^{25)}$ and the management of hypertension and coronary artery disease. It is used effectively in the treatment of supraventricular and ventricular premature beats and tachycardia, and in the prophylaxis of paroxysmal arrhythmias.

It may be given orally for antiarrhythmic purposes in doses of 15 to $30 \mathrm{mg}$, or intravenously at a dose of 4 to $12 \mu \mathrm{g} / \mathrm{Kg}$ of body weight.

In this study, the intravenous administration of pindolol to anesthetized 
dogs was performed in a dose range of 4 to $40 \mu \mathrm{g} / \mathrm{Kg}$. The latter dosage of pindolol is above what is considered therapeutically safe in man.

Significant effects of intravenous pindolol were observed on sinus cycle length, the A-V nodal conduction time, the ERP of the atrium, the ERP and FRP of the A-V node, and the ERP of the ventricle.

Hill and Turner reported that pindolol with intrinsic sympathomimetic activity, produced less fall in resting heart rate in normal man compared with propranolol. ${ }^{25)}$ In our experiment, sinus cycle length was prolonged, slightly in group 1 but greatly in groups 2 and 3 . It seems that beta-blocking action may markedly dominate in overdosis of pindolol. The intraatrial conduction time was not altered by pindolol, while the ERP of the atrium was slightly increased. In prior studies in man, pindolol only slightly prolonged the ERP of the atrium. ${ }^{20)}$ Seides et al reported that the ERP of the atrium was increased by intravenous propranolol in man. ${ }^{5)}$ Josephson et al. described that the ERP of the atrium was increased by a mean of $24 \mathrm{msec}$ in 17 out of 21 patients after administration of intramuscular quinidine. ${ }^{21}$ )

In the present study, the A-H interval was generally increased by pindolol without Wenckebach type A-V block, but the $\mathrm{H}-\mathrm{V}$ interval was unchanged. Therefore, our observations showed that pindolol exerted an influence mostly upon the A-V nodal conduction time in canine hearts, while it showed a lack of the effects on the His-Purkinje conduction time with a large amount of the drug. This feature is similar to those of beta-adrenergic blocking agents such as propranolol etc, in contrast to procaine amide, or quinidine. ${ }^{53,19), 22), 26)}$

In most previous reports, it has been shown that the conduction in the His-Purkinje system is insensitive to beta-adrenergic receptor stimulation or blockade. ${ }^{57,27)}$ Thus, unlike procaine amide and quinidine, which depressed the His-Purkinje conduction, pindolol might therefore be indicated in the treatment of arrhythmias which are associated with some degree of intraventricular block.

Both ERP and FRP of the A-V node were lengthened by intravenous pindolol in the intact canine heart. These results in our studies with the increase in the $\mathrm{A}-\mathrm{V}$ nodal conduction time are in agreement with those in man reported by Di Biase et al.20) These findings may be explained by the betablocking activities of pindolol.

In previous studies, Seides et al reported that propranolol increased the ERP and FRP of the A-V node in man, without consistent effects on the HisPurkinje system, and differed from quinidine and procaine amide in that these drugs decreased the refractory periods of the A-V node and increased the refractory periods of the His-Purkinje system. ${ }^{5}$ "The mechanism of action of beta-blocking agent such as propranolol has been ascribed to both its beta- 
adrenergic blocking properties and its properties as a membrane stabilizing local anesthetics. ${ }^{8,26)}$ Pindolol slightly prolonged the ERP of the ventricle, which might be regarded as a result due to the membrane stabilizing action.

Since no block within the His-Purkinje system or prolongation of the $\mathrm{H}-\mathrm{V}$ interval was produced and only a few QRS complexes by extrastimulus showed aberrant configuration in the intact canine heart, the ERP and RRP of the His-Purkinje system were not statistically evaluated. This may be involved in the relationship between the cycle length and cardiac refractory periods. ${ }^{28}$ In our studies, the sinus rates of anesthetized dogs without chest opening were 160 to $200 / \mathrm{min}$. Atrial pacing rates were 170 to $220 / \mathrm{min}$, so that the basic driving stimulus might be slightly faster than the underlying sinus rate. If we studied on the open chest dogs, some blocks might have occurred within the His-Purkinje system at slower sinus rates of about 100 to $140 / \mathrm{min}$.

Finally, with regard to the effect of pindolol on the atrioventricular conduction time, the result without atrial pacing was statistically less dispersed than that under atrial pacing. We should evaluate the effect of the agent on the cardiac conduction time in future studies.

\section{ReFERENCES}

1. Lemberg L, Castellanos A, Arcebal AG: The use of propranolol in arrhythmias complicating acute myocardial infarction. Am Heart J 80:479, 1970

2. Aroesty JM, Cohen J: The effects of beta-adrenergic blocking agent, propranolol, on digitalis induced ventricular arrhythmias. Am Heart J 71: 503, 1966

3. Gibson D, Sowton E: The use of beta-adrenergic receptor blocking drugs in dysrhythmias. Progr Cardiovasc Dis 12: 16, 1969

4. Jewitt DE, Singh BN: The role of $\beta$-adrenergic blockade in myocardial infarction. Progr Cardiovasc Dis 16: 421, 1974

5. Seides SF, Josephson ME, Batsford WP, Weisfogel GM, Lau SH, Damato AN: The electrophysiology of propranolol in man. Am Heart J 88 : 733, 1974

6. Dunlop D, Shanks RG: Selective blockade of adrenoceptive beta receptors in the heart. Brit J Pharmac Chemother 32: 201, 1968

7. Shinebourne E, White R, Hamer J: A qualitative distinction beta-receptor-blocking and local anesthetic actions of antiarrhythmic agents. Circulat Res 114: 835, 1969

8. Wit AL, Hoffman BF, Rosen MR: Electrophysiology and pharmacology of cardiac arrhythmias IX. Cardiac electrophysiologic effects of beta-adrenergic receptor stimulation and blockade. Part C. Am Heart J 90: 795, 1975

9. Hecht HH, Kossmann CE, Childers RW, Langendorf R, Lev M, Rosen KM, Pruitt RD, Truex RC, Uhley HN, Watt TB: Atrioventricular and intraventricular conduction. Am J Cardiol $31: 232,1973$

10. Scherlag BJ, Lau SH, Helfant RH, Stein E, Berkowitz WD, Damato AN: Catheter technique for recording His bundle activity in man. Circulation 39: 13, 1969

11. Damato AN, Lau SH, Helfant RH, Stein E, Berkowitz WD, Cohen SI: Study of atrioventricular conduction in man using electrode catheter recordings of His bundle activity. Circulation 39: 287, 1969 
12. Damato AN, Gallagher JJ, Lau SH: Application of His bundle recordings in diagnosing conduction disorders. Progr Cardiovasc Dis 16:601, 1972

13. Scherlag BJ, Lazzara R, Helfant RH: Differentiation of A-V junctional rhythms. Circulation 48: 304, 1973

14. Wallace AD, Boineau JP, Davidson RM: Wolf-Parkinson-White syndrom: A new look. Am J Cardiol 28: 509, 1971

15. Rosen KM, Lau SH, Weiss MB, Damato AN: The effect of lidocaine on atrioventricular and intraventricular conduction in man. Am J Cardiol 25: 1, 1970

16. Josephson ME, Caracta AR, Lau SH, Gallagher JJ, Damato AN: Effects of lidocaine on refractory periods in man. Am Heart J 84: 778, 1972

17. Josephson ME, Caracta AR, Lau SH, Gallagher JJ, Damato AN: Electrophysiological evaluation of disopyramide in man. Am Heart J 86: 771, 1973

18. Befeler B, Castellanos A, Wells DE, Vagueiro MC, Yen BK: Electrophysiologic effects of the antiarrhythmic agent disopyramide phosphate. Am J Cardial 35: 282, 1975

19. Josephson ME, Caracta AR, Ricciutti MA, Lau SH, Damato AN: Electrophysiologic properties of procaine amide in man. Am J Cardiol 33: 596, 1974

20. Biase $\mathrm{MD}$, Brindicci G, Rizzon P: Effects of pindolol on impuluse formation and conduction in man. Electrocardiology 10:45, 1977

21. Josephson ME, Seides SF, Batsford WP, Weisfogel GM, Akhtar M, Caracta AR, Damato AN: The electrophysiological effects of intramuscular quinidine on the atrioventricular conducting system in man. Am Heart J 87: 55, 1974

22. Saameli K: Studies with beta-receptor blockers on the isolated atrium of the guinea pig. Helv Physiol Pharmacol Acta 25: 219, 1967

23. Hill RC, Turner P: Preliminary investigations of a new beta-adrenoceptive receptor blocking drug, LB-46, in man. Brit $J$ Pharmacol 36: 368, 1969

24. Lubawski I, Wale J: Studies with LB-46, a new $\beta$-receptor blocking drug. Europ J Pharmacol 6: 345, 1969

25. Jewitt DE, Singh BN: Treatment of arrhythmias with pindolol. Clin Pharmacol Ther 13: 15,1971

26. Singh BN, Hauswirth $\mathrm{O}$ : Comparative mechanisms of action of antiarrhythmic drugs. Am Heart J 87: 367, 1974

27. Priola DV: Effects of beta receptor stimulation and blockade on A-V nodal and bundle branch conduction in the canine heart. Am J Cardiol 31 : 35, 1973

28. Denes $\mathbf{P}, \mathbf{W u} \mathrm{D}$, Dhingra R, Pietras RJ, Rosen KM: The effects of cycle length on cardiac refractory periods in man. Circulation 49: 32, 1974 